\title{
Investigation on speciation and pollution index of heavy metals in River Ala sediment, Akure, Nigeria
}

\author{
Ademola Festus AIYESANMI *, Ayobami Ayokunle OGUNTUASE and \\ Gideon Aina IDOWU \\ Chemistry Department, Federal University of Technology, P.M.B.704, Akure, Nigeria. \\ *Corresponding author, E-mail: demolaktp@yahoo.co.uk, Tel: +2348033501293
}

\begin{abstract}
This study investigated the chemical speciation of $\mathrm{Cd}, \mathrm{Cr}, \mathrm{Cu}, \mathrm{Ni}$ and $\mathrm{Pb}$ and their contamination/ pollution indices in the sediment of River Ala in Akure, Nigeria. Sediment samples taken along the course of the river were subjected to Sequential Extraction Technique and the heavy metals were quantified using atomic absorption spectrophotometer. Varied distribution of metals among the chemical fractions was recorded, with contribution from both anthropogenic and geogenic sources to the total heavy metals concentration in the sediment. Pollution/contamination index evaluation showed that the sediment fall within the "very slight and "moderate contamination" range with respect to $\mathrm{Cr}, \mathrm{Cu}, \mathrm{Ni}$ and $\mathrm{Pb}$ and in the moderate pollution range with Cd.

(C) 2010 International Formulae Group. All rights reserved.
\end{abstract}

Keyword: Sequential extraction, pollution/contamination index.

\section{INTRODUCTION}

The term "benthic environment" has been used to describe the bottom of water bodies or sediments where both large and small creatures like crabs, crustaceans, worms and insect larvae inhabit (USEPA, 2008). The water body is generally exposed to different kinds of contaminants from natural sources and anthropogenic activities, including municipal and industrial wastes disposal, application of pesticides and fertilizers. The benthic region or sediment is known to act as "sink" i.e. reservoir for most of these contaminants in the aquatic environment (Mudre and Ney, 1986). The contamination of water sediments has several effects on the ecosystem. Species that cannot tolerate the toxic contaminants found in water sediment simply die, leading to a general loss of biodiversity. Animals that survive exposure to contaminated sediment may develop serious health problems and reproductive impairments (USEPA, 2008). Again, contaminated sediments do not always remain at the bottom of the water body, anything that stirs up the water, such as storm, can re-suspend some sediment, meaning that all aquatic biota, and not just the bottom dwellers, may be directly exposed to toxic contaminants. Of greater concern is the fact that some of these 
contaminants bioaccumulate and biomagnify in aquatic organisms on ingestion, and ultimately enter the food chain where man stands at the targeted end (Murphy, 1981).

Heavy metals have been identified as a major class of contaminants associated with water sediments. Heavy metals, being inorganic cannot be degraded or destroyed in the aquatic environment and are generally toxic even at low concentrations (Murphy, 1981; Ademoroti, 1996; Rognerad and Field, 2001; Gale et al., 2004). The primary concern for metals in sediments is toxicity to benthos (Adams et al., 1992; Long et al., 1995; DEC, 1999; Muohi et al., 2003). The potential adverse impacts of heavy metals on aquatic life and wildlife as well as humans are many and varied. Evidence of potential and observed human hazard due to environmentally acquired heavy metals and their ecological impact have been extensively studied and documented (Murphy, 1981; Ademoroti, 1996, Muohi et al., 2003).

While total metal content is a critical measure in assessing risk of contaminated sediment, it does not alone provide predictive insights on the bioavailability, mobility and fate of the metal contaminants (Bermond et al., 1998; Sauz-metal, 1998; Nolan et al., 2003). Scientific community has concluded that bioavailability, bioactivity, biogeological distribution/transportation, uptake, transport in the organism, toxicity and, thus, the eventual impact of the toxic elements will be dictated by the particular species or form in which they are present in the sample (Gruebel et al., 1988; Förstner, 1993; Ostergren et al., 1999; Calmano et al., 2001; Scheinost et al., 2002; Apte et al., 2004). Therefore, speciation information to complement total toxic element determinations is being increasingly demanded, both in environmental and in chemical/biological issues. Hence, the focus of this study was to investigate some heavy metal contaminants present in the sediment of Ala River, the chemical forms in which they exist and the extent of contamination/pollution of the river sediments by the metals.

\section{MATERIALS AND METHODS}

Study area

Ala River is a major river that transverses through the entire length of Akure metropolis, in Ondo State, Nigeria (Figure 1). By virtue of its location, it has become a major sink to municipal runoff and cocktail of domestic and municipal wastes that are indiscriminately disposed at its banks. Minor fishing activities take place at different locations along the course of the river, and water from the river in some areas is used for irrigation and supply to earthen fish pond operation.

\section{Sampling}

Grab sediment samples were obtained using a Van ven grab from four different locations along the course of Ala River in Akure. The sampling points along the river course are as indicated in the map (Figure 1). The sampling locations and geographical references of sampling points taken with a Global Positioning System (Garmin GPS 12 model) were: Okuta- Elerinla $-\mathrm{P}_{1}\left(007^{0}\right.$ $\left.16.26 \mathrm{~N}, 005^{0} 10^{\prime} 02 \mathrm{E}\right)$; Aiyedun $-\mathrm{P}_{2}\left(007^{0}\right.$ $\left.15,52 \mathrm{~N}, 005^{0} 11^{\prime} 24 \mathrm{E}\right)$; Ijomu/Okeiebu - $\mathrm{P}_{3}$ (0070 15' 47N, 005012 ' 15E); and Alagbaka $\begin{array}{llllll}-\mathrm{P}_{4} & \left(007^{0}\right. & 15 & 21 \mathrm{~N}, & 005^{0} & 13\end{array}$ Preservation of samples was carried out as prescribed by US Geological Survey (1989).

\section{Sample treatment and analysis}

Samples were air-dried in the laboratory for 2 weeks. They were then ground into fine particles in a mortal, sieved through a $2 \mathrm{~mm}$ mesh and about $200 \mathrm{~g}$ of the sieved samples were sub-sampled by quartering for analysis. $5 \mathrm{~g}$ of sample were dried at $105{ }^{\circ} \mathrm{C}$ in an oven to a constant weight to determine the percentage dry matter content. The $\mathrm{pH}$ of the sediment samples in water was determined by method described by 
Hendershot et al. (1993) using a Jenway $\mathrm{pH}$ meter. The organic carbon was determined using the wet oxidation method of Walkley and Black (Aiyesanmi, 2008), while the particle size was determined by the hydrometer method described by Shedrick and Wang (1993).

The sequential extraction described by Rauret et al. (1988) and Aiyesanmi et al. (2008) was used for the chemical fractionation of metals in the sediment. The sequential extraction procedure evaluates the distribution of heavy metals among the Exchangeable (Exch), Carbonate (Carb), Easily-Reducible or Oxide (Oxd), Organic (Org), and Residual forms in the sediment. The extracts along with blanks were analyzed with Atomic Absorption Spectrophotometer (AAS) ALPHA 4 Model for cadmium $(\mathrm{Cd})$, chromium $(\mathrm{Cr})$, copper $(\mathrm{Cu})$, nickel $(\mathrm{Ni})$ and lead $(\mathrm{Pb})$. Evaluation of the accuracy of the analytical method was carried out using SOIL-7 Certified Reference
Material obtained from International Atomic Energy Agency (IAEA). All analyses were conducted in triplicate to evaluate precision.

\section{Data analysis}

Data generated on total concentrations of each metal were analyzed for spatial variation using one way analysis of variance (ANOVA) with SPSS package. One level of significance $(\mathrm{p}<0.05)$ was considered in the results interpretation.

\section{RESULTS AND DISCUSSION}

The results of some specific physicochemical characteristics of Ala River sediment are presented in Table 1. A persistently low $\mathrm{pH}$ values of between $5.84 \pm 0.20$ and $6.50 \pm 0.12$ were recorded, which falls within the medium to slightly acidic range according to the classification of soils and sediments $\mathrm{pH}$ by Vitosh et al. (1995).

Table 1: Some specific physico-chemical characteristics of River Ala sediments.

\begin{tabular}{lccccc}
\hline Sample Location & pH & TOC (\%) & Sand (\%) & Clay (\%) & Silt (\%) \\
\hline Okuta-Elerinla & $5.84 \pm 0.20$ & $3.80 \pm 0.28$ & $70.35 \pm 1.65$ & $26.01 \pm 1.33$ & $3.64 \pm 0.33$ \\
Aiyedun & $6.46 \pm 0.10$ & $3.68 \pm 0.33$ & $75.52 \pm 1.30$ & $21.10 \pm 0.67$ & $3.38 \pm 0.42$ \\
Ijomu/Oke-Ijebu & $6.42 \pm 0.16$ & $3.94 \pm 0.52$ & $76.55 \pm 2.10$ & $19.88 \pm 1.54$ & $3.57 \pm 0.20$ \\
Alagbaka & $6.50 \pm 0.12$ & $3.56 \pm 0.43$ & $79.58 \pm 1.20$ & $17.10 \pm 0.75$ & $3.32 \pm 0.67$ \\
\hline
\end{tabular}

TOC = Total Organic Carbon

Table 2: Observed and certified values $(\mathrm{mg} / \mathrm{kg})$ for IAEA SOIL-7 CRM.

\begin{tabular}{llcc}
\hline & $\mathbf{C d}$ & $\mathbf{C u}$ & $\mathbf{P b}$ \\
\hline Observed values $^{\mathrm{a}, \mathrm{b}}$ & $2.30 \pm 0.22$ & $12.36 \pm 0.30$ & $68.65 \pm 1.60$ \\
Certified values $^{\mathrm{c}}$ & $1.1-2.7$ & $9.0-13.0$ & $55.0-71.0$ \\
\hline total of fractions ${ }^{\mathrm{b}}$ Mean of replicate analysis $(\mathrm{n}=3){ }^{\mathrm{c}}$ Neutron activated analysis, AAS, Fluorimetry, Emission \\
oscopy, Colorimetry, Volumetry, with or without separation and sample pre-treatment and preconcentration steps \\
ytical Quality Control Service - IAEA, Austria)
\end{tabular}




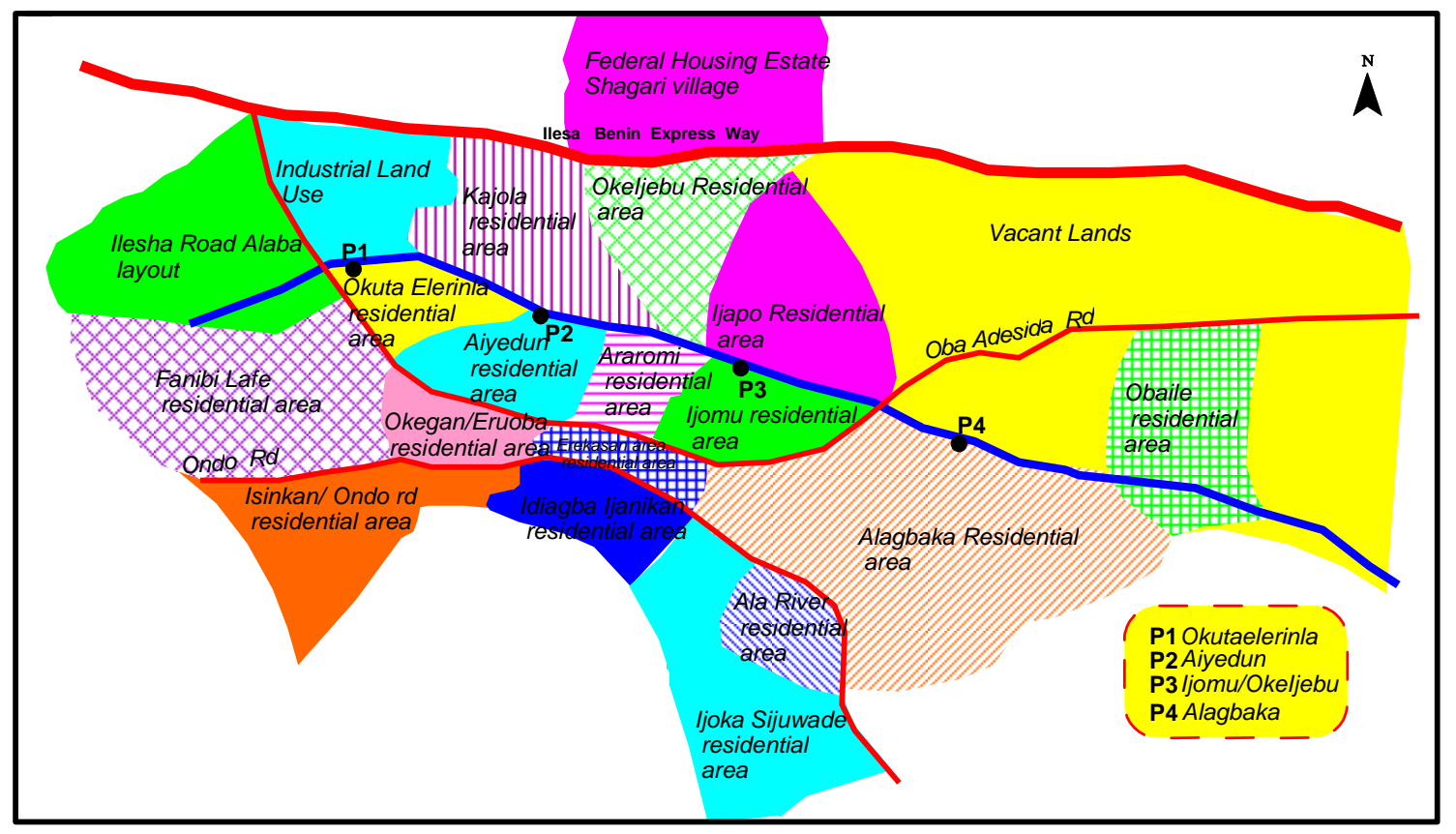

Figure 1: Map of Akure showing River Ala and the sampling point.

The mobility/solubility of trace metals in contaminated sediment and soil is strongly affected by the $\mathrm{pH}$ (Campbell, 1995; Tack and Verloo, 1997; Aiyesanmil, 2008; Aiyesanmi et al., 2008). Low $\mathrm{pH}$ condition (i.e. acidic nature) of soil/sediment facilitates leaching and mobility of metals present in sediments and soils, thus suggesting the possibility of leaching of metals and subsequent transfer into the water column, making them available to the aquatic organisms uptake. High soil or sediment acidity has been attributed to combination of possible oxidation of pyrite $\left(\mathrm{FeS}_{2}\right)$ in the soil/sediment to produce sulphuric acid, depleted calcium level or increased aluminium concentration in soil/sediment (Aiyesanmi, 2008).

The total organic carbon determined in the sediment samples ranged between $3.56 \pm 0.43 \%$ and $3.94 \pm 0.52 \%$, while the sand, clay and silt contents were between $70.35 \pm 1.65$ - $79.58 \pm 1.20 \%, 17.10 \pm 0.75-$ $26.01 \pm 1.33 \%$ and $3.32 \pm 0.67-3.64 \pm 0.33 \%$ respectively. Clay and organic carbon/matter have direct influence on other physical and chemical characteristics of soil/sediment, including reserve of exchanged bases and the interaction and dynamics of trace metals. Hence, maximum soil/sediment capacity for heavy metals is adjusted according to these macro-parameters (Lacatusu, 2000; DPR, 2002). Metals such as $\mathrm{Cd}, \mathrm{Cu}, \mathrm{Pb}$ and $\mathrm{Zn}$ have been reported with high tendency of binding tenaciously to organic matter contained in soil, sediment and suspended particulate within the water column (Gale et al., 2004). Organically bound metals may dissociate as free ions and participate in cation exchange reactions with various minerals and living organism, depending on ambient $\mathrm{pH}$, ionic strength and temperature. Thus, the organic matter of sediments is known to play a major role in determining the bioavailability of heavy metals (Gale et al., 2004; Aiyesanmi, 2008). 
Table 3: Speciation of chemical fractions of heavy metals in River Ala sediment.

\begin{tabular}{|c|c|c|c|c|c|c|}
\hline Location & Chemical fraction & Cd & $\mathbf{C r}$ & $\mathbf{C u}$ & $\mathbf{N i}$ & $\mathbf{P b}$ \\
\hline \multirow{5}{*}{ Okuta-Elerinla } & Exchangeable & 0.59 & 2.13 & 1.07 & 3.72 & 2.37 \\
\hline & Carbonate & 1.80 & 0.76 & ND & 2.12 & 0.35 \\
\hline & Oxide & 0.04 & 1.34 & 10.10 & 6.62 & ND \\
\hline & Organic & 0.75 & ND & 3.42 & 3.40 & 2.29 \\
\hline & Residual & ND & 14.54 & 8.53 & 9.24 & 7.76 \\
\hline \multirow{5}{*}{ Aiyedun } & Exchangeable & 1.10 & 1.98 & 4.12 & ND & 1.84 \\
\hline & Carbonate & 0.38 & 0.86 & ND & 3.08 & 0.17 \\
\hline & Oxide & ND & 0.32 & 6.37 & 2.40 & ND \\
\hline & Organic & 0.21 & ND & 4.60 & 3.40 & 0.33 \\
\hline & Residual & 0.46 & 13,92 & 3.62 & 5.30 & 4.46 \\
\hline \multirow{5}{*}{ Ijomu/Oke-Ijebu } & Exchangeable & 1.10 & 1.49 & 2.46 & ND & 1.96 \\
\hline & Carbonate & 0.16 & 0.77 & ND & $\mathrm{ND}$ & 3.34 \\
\hline & Oxide & ND & 1.57 & 5.19 & 3.06 & 0.59 \\
\hline & Organic & 0.05 & 0.49 & 2.24 & 0.85 & 0.19 \\
\hline & Residual & 0.87 & 11.57 & 4.00 & 3.18 & 5.02 \\
\hline \multirow{5}{*}{ Alagbaka } & Exchangeable & 0.87 & 1.64 & 1.31 & 3.76 & 1.67 \\
\hline & Carbonate & 0.63 & 0.54 & ND & $\mathrm{ND}$ & 4.20 \\
\hline & Oxide & ND & 0.17 & 6.98 & ND & 1.48 \\
\hline & Organic & 0.99 & ND & 2.47 & 2.13 & ND \\
\hline & Residual & ND & 12.60 & 2.48 & 7.03 & 2.18 \\
\hline
\end{tabular}

Table 4: Mean total concentration of heavy metals in River Ala sediments (mg/kg).

\begin{tabular}{lccccc}
\hline Sample Location & $\mathbf{C d}$ & $\mathbf{C r}$ & $\mathbf{C u}$ & $\mathbf{N i}$ & $\mathbf{P b}$ \\
\hline Okuta-Elerinla & $3.18^{\mathrm{a}}$ & $18,77^{\mathrm{a}}$ & $23.12^{\mathrm{a}}$ & $21,70^{\mathrm{a}}$ & $12.77^{\mathrm{a}}$ \\
Aiyedun & $2.15^{\mathrm{b}}$ & $17.08^{\mathrm{a}}$ & $18.71^{\mathrm{b}}$ & $14.18^{\mathrm{b}}$ & $6.80^{\mathrm{c}}$ \\
Ijumo/Oke-Ijebu & $2.18^{\mathrm{b}}$ & $15.89^{\mathrm{a}}$ & $13.89^{\mathrm{c}}$ & $7.09^{\mathrm{c}}$ & $11.10^{\mathrm{a}}$ \\
Alagbaka & $2.49^{\mathrm{b}}$ & $14.95^{\mathrm{a}}$ & $13.24^{\mathrm{c}}$ & $12.92^{\mathrm{b}}$ & $9.53^{\mathrm{b}}$ \\
\hline
\end{tabular}

Superscripts with the different letters down the column show significant variation, while those with the same letter does not at $\mathrm{p}<0.05$.

Table 2 compares the results of the value of total metal extracted to that specified for the reference soil sample used (IAEA Soil -7 CRM). The results indicate a close agreement between the experimental and certified values, hence confirming the accuracy of both the sequential extraction procedure and the Atomic Absorption Spectrophotometric technique employed.
Table 3 presents the chemical forms of the heavy metals studied in the sediment samples. The values were used to estimate the percentage of each fraction on the mean total concentration for each metal in the sediment samples. The distribution of Cadmium (Cd) among the fractions follows the order: Exch $(36.60 \%)>\operatorname{Carb}(29.70 \%)>\operatorname{Org}(20.00 \%)>$ Res $(13.30 \%)>$ Oxd $(0.40 \%)$. The observed 
A. F. AIYESANMI et al. / Int. J. Biol. Chem. Sci. 4(6): 2348-2359, 2010

Table 5: Heavy metal pollution appraisal in River Ala sediment.

\begin{tabular}{|c|c|c|c|c|c|c|c|c|}
\hline$\overline{\text { Location }}$ & V.s.l & $\mathbf{m . l}$ & s.t.l v.s.t.l & $\begin{array}{c}\text { Multiple. } \\
\text { Contamination }\end{array}$ & s.p & m.p & s.t.p v.s.t.p e.p & Multiple Pollution \\
\hline$\overline{\text { Okuta-Elerinla }}$ & & $\mathrm{Cr} / 0.10 \mathrm{~Pb} / 0.10 \mathrm{Cu} / 0.39 \mathrm{Ni} / 0.27$ & & 0.86 & & $\mathrm{Cd} / 3.21$ & & 3.21 \\
\hline Aiyedun & $\mathrm{Cr} / 0.09 \mathrm{~Pb} / 0.05$ & $\mathrm{Cu} / 0.30$ & & 0.62 & & $\mathrm{Cd} / 2.17$ & & 2.17 \\
\hline Ijomu / Oke-Ijebu & $\begin{array}{c}\mathrm{Cr} / 0.08 \mathrm{Ni} / 0.08 \\
\mathrm{~Pb} / 0.09\end{array}$ & $\mathrm{Cu} / 0.22$ & & 0.47 & & $\mathrm{Cd} / 2.20$ & & 2.20 \\
\hline Alagbaka & $\mathrm{Cr} / 0.08 \mathrm{~Pb} / 0.08$ & $\mathrm{Cu} / 0.22 \mathrm{Ni} / 0.16$ & & 0.54 & & $\mathrm{Cd} / 2.51$ & & 2.51 \\
\hline
\end{tabular}

Table 6: Significance of intervals of contamination/pollution index $(\mathrm{C} / \mathrm{p})$.

\begin{tabular}{llc}
\hline $\mathbf{C} / \mathbf{p}$ & Significance & Symbol \\
\hline$<0.1$ & Very slight contamination & v.s.l \\
$0.10-0.25$ & Slight contamination & s.l \\
$0.26-0.50$ & Moderate contamination & m.l \\
$0.51-075$ & Severe contamination & s.t.l \\
$0.76-1.00$ & Very severe contamination & v.s.t.l \\
$1.1-2.0$ & Slight pollution & s.p \\
$2.1-4.0$ & Moderate pollution & m.p \\
$4.1-8.0$ & Severe pollution & s.t.p \\
$8.1-16.0$ & Very severe pollution & v.s.t.p \\
$>16.0$ & Excessive pollution & e.p
\end{tabular}




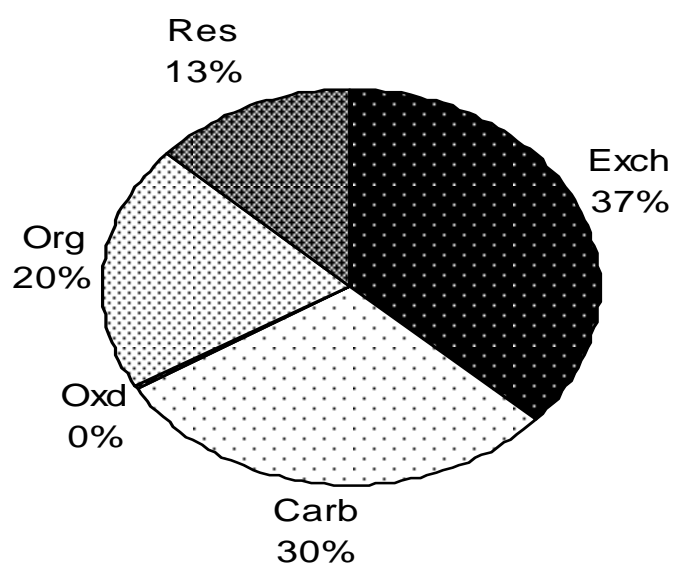

Figure 2a: Relative partitioning of $\mathrm{Cd}$ in chemical fractions.

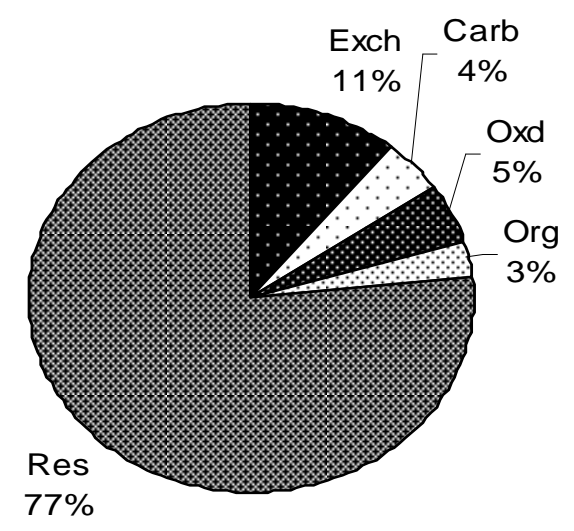

Figure 2b: Relative partitioning of $\mathrm{Cr}$ in chemical fractions.

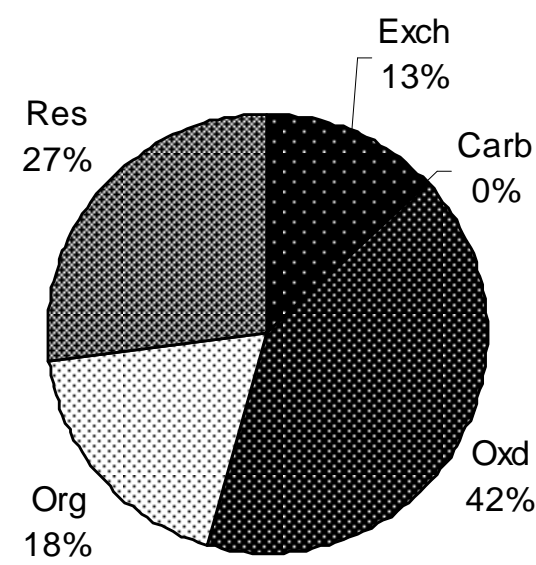

Figure 2c: Relative partitioning of $\mathrm{Cu}$ in chemical fractions. 


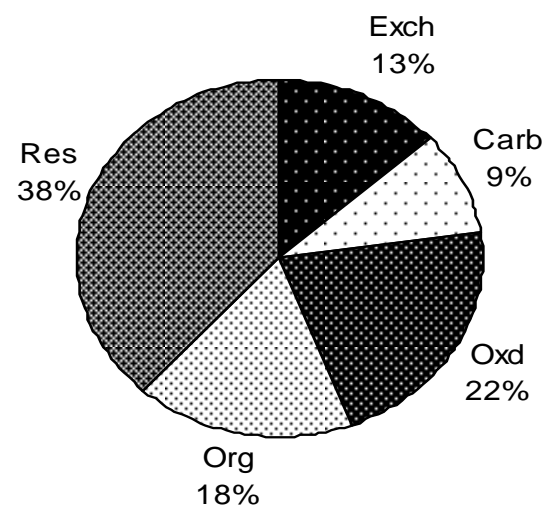

Figure 2d: Relative partitioning of $\mathrm{Ni}$ in chemical fractions.

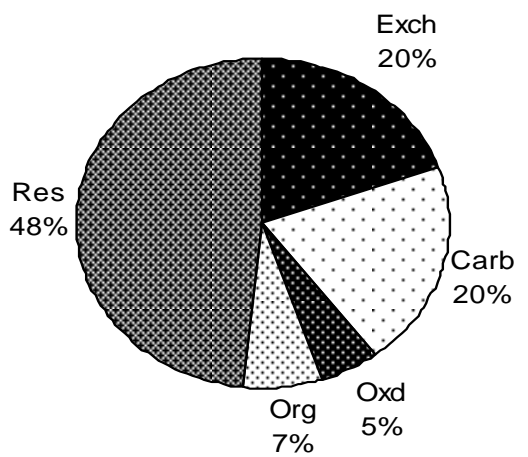

Figure 2e: Relative partitioning of $\mathrm{Pb}$ in chemical fractions.

relatively high concentration of $\mathrm{Cd}$ in the exchangeable fraction supports earlier reports that $\mathrm{Cd}$ is easily leached into soil solution, since the exchangeable fraction is the most mobile (Gale et al., 2004; Aiyesanmi et al., 2008). Amuda et al. (2005) related the residual fraction and the non- residual fractions of heavy metals in sediment to natural and anthropogenic sources respectively, which suggests a significant contribution from anthropogenic sources to the Cd level measured in Ala River sediment.

The partitioning of Chromium $(\mathrm{Cr})$ in the sediment samples showed the order: Res $(76.71 \%)>\operatorname{Exch}(10.86 \%)>$ Oxd $(5.10 \%)>$ Carb (4.39\%) > Org (2.94\%). Chromium found in the sediment is largely of geogenic or natural source since it is mostly concentrated in the residual fraction, while all the nonresidual fractions altogether constitute $23.29 \%$. Similarly, Nickel (Ni) also showed the highest distribution of $38.21 \%$ in the residual fraction, while other fractions gave the order of $\operatorname{Oxd}(21.61 \%)>\operatorname{Org}(17.50 \%)>$ $\operatorname{Exch}(13.38 \%)>$ Carbonate $(9.30 \%)$. This agrees with earlier findings on similar studies that $\mathrm{Ni}$ in soil and sediment has a moderate tendency of binding to the silicate (Egila and Nimyeh, 2002; Aiyesanmi et al., 2008). However, nickel levels in the sediment could be attributed to both anthropogenic and geogenic contributions as the non-residual and residual fractions account for $61.79 \%$ and $38.21 \%$ of the mean total concentration respectively. The high concentrations of $\mathrm{Cr}$ and $\mathrm{Ni}$ found in this residual fraction are, 
however, not likely to be available to the aquatic organisms or enter the food chain since the residual fraction is very stable, less reactive and less bio-available. Heavy metals found in this matrix are believed to be trapped and occluded within crystal lattice of layer of silicate and well crystallized oxide minerals (Egila and Nimyeh, 2002). Tessier and Campbell (1987) had also reported that metals found in the residual fraction are not expected to be released in solution over a reasonable time span under the conditions normally encountered in nature.

The occurrence of Copper $(\mathrm{Cu})$ in the sediment could be attributed to both geogenic and anthropogenic, with the highest concentration recorded in the oxide fraction. The oxide fraction is said to be relatively stable (slowly mobile; poorly available) but could change with variation in redox conditions, becoming more soluble under reducing conditions and less so under oxidizing one. The extent and intensity of these processes will, however, vary depending on several factors associated with oxygen dynamics in the soil (Egila and Nimyeh, 2002, Aiyesanmi et al., 2008). It follows, therefore, that $\mathrm{Cu}$ in the oxide fraction can be released into the water body under favourable environmental conditions. The partitioning of $\mathrm{Cu}$ in the sediment gave $\mathrm{Oxd}(41.52 \%)>$ $\operatorname{Res}(27.02 \%)>\operatorname{Org}(18.46 \%)>$ Exch(13.00\%). It should be noted that $\mathrm{Cu}$ was not detected in the carbonate fraction and this is consistent with other studies that the carbonate fraction, which is slowly mobile and relatively stable, generally does not retain large concentrations of heavy metals (Egila and Nimyeh, 2002; Aiyesanmi et al., 2008). Also, Lead $(\mathrm{Pb})$ measured in the river sediment was of both natural and anthropogenic origin, with percentage abundance of $48.25 \%$ ) in the residual fraction. Other fractions recorded $\mathrm{Carb}(20.10 \%)>$ $\operatorname{Exch}(19.50 \%)>\operatorname{Org}(6.99 \%)>\operatorname{Oxd}(5.15 \%)$. Figures $(2 \mathrm{a}-2 \mathrm{e})$ show the relative partitioning of the studied metals in the various chemical fractions: (Exch, Carb, Oxd, Org, and Res), as percentage of mean total concentration of the metal in the river sediment.

Table 4 shows the mean concentrations of the metals measured at the four sampling locations as a general indication of the level of the measured heavy metals in Ala River Sediment. There exists marked variation in the mean concentrations of these metals at $\mathrm{p}<$ 0.05 indicated by different superscripts. This information could serve as baseline level of these metals in the sediment with which progressive anthropogenic influence on the river can be evaluated. However, assessment of sediment for heavy metal pollution based on the absolute metal content values provides inadequate information on the significance of the values obtained with the intrinsic sediment features and how the values are related to the maximum allowable limits for each metal (Lacatusu, 2000; Aiyesanmi, 2008). Also, because a metal concentration in the aquatic environment is considered to be naturally occurring or background does not mean that the concentration is not causing an adverse ecological effect (Persaud et al., 1992). Thus, an appraisal of heavy metal contamination or pollution of the sediment following the scheme prescribed by Lacatusu (2000) is presented in Table 5. Contamination/pollution $(\mathrm{C} / \mathrm{P})$ index was calculated as a ratio of heavy metals effectively measured in the sediment by chemical analysis to the target/reference value of contamination on normalized sediment obtained by calculation for the sediment, using a conversion formula that takes into account the clay and organic contents of the sediment (DPR, 2002; Aiyesanmi, 2008). The calculated $\mathrm{C} / \mathrm{P}$ indices were interpreted according to the scheme presented in Table 6. Because of possible occurrence of synergy among metals, even at low concentrations, the values defining the $\mathrm{C} / \mathrm{P}$ range were totaled, obtaining in this case the values of Multiple Contamination and Multiple Pollution with respect to the 
measured heavy metals, the values which were also interpreted according to the scheme in Table 6. The pollution index assessment indicates that most of the metals fall within the "very slight contamination" and "moderate contamination" range in the sediment. In all, the sediment is found to be mostly polluted by cadmium, being found in the "moderate pollution" range in all the locations. The Multiple Contamination/Pollution obtained from the analyses showed that Ala River sediment recorded moderate to very severe contamination and moderate pollution respectively. It is not unlikely that human activities utilizing and/or generating metal and metal scraps, such as the proliferated auto mechanic workshops at Okuta-Elerinla area in particular and pockets of such in other sampling areas, coupled with heaps of solid wastes dumped indiscriminately around and along the course of the River, contribute significantly to the anthropogenic contamination of the sediment.

\section{Conclusion}

Our study of speciation of heavy metals in Ala River sediment through the Sequential Extraction Procedure led to the detection of differing concentrations of $\mathrm{Cd}, \mathrm{Cr}, \mathrm{Cu}, \mathrm{Ni}$, and $\mathrm{Pb}$ in the sediment. The study also provides baseline information on the concentration of the metals in the river sediment with which future anthropogenic influences could be evaluated. Contribution to the total metal content of the sediment was from both geogenic and anthropogenic sources. The pollution indices determination showed that most of the metals are within the slight and moderate contamination range, with moderate pollution of the sediment resulting from cadmium. The anoxic (low $\mathrm{pH}$ ) condition of the sediment may facilitate the transfer and leachability of the heavy metals into the water column, thereby increasing their availability to aquatic organisms, in particular the fish. It therefore becomes necessary to carry out further studies on the levels of these metals in the water column and their accumulation in fishes and other aquatic biota in the river to ascertain possible entrance of metals into the food chain.

\section{REFERENCES}

Adams WJ, Kimerle RA, Barnett JW Jr. 1992. Sediment quality and aquatic life assessments. Environ. Sci. Tech., 26(10): 1865 - 1875 .

Ademoroti CMA. 1996. Environmental Chemistry and Toxicology. Foludex Press Ltd.: Ibadan, Nigeria.

Aiyesanmi AF. 2008. Baseline heavy metals concentration in river sediments within okitipupa southeast belt of the Nigerian bituminous sands field. . J. Chem. Soc. Nig., 33(2): 29 - 41.

Aiyesanmi AF, Tomori WB, Owolabi BJ. 2008. Relative partitioning of some heavy metals in dumpsite soil using chemical speciation technique. Intern. J Chem. Sci., 1(1): 96 - 104.

Amuda OS, Onianwa PC, Ayodele ET, Imeokparia FE. 2005. Trace metals contamination of lake sediment in Ibadan, Nigeria. Intern. J. Bio. Appl. Sci., 10(3): 121- 128.

Apte SC, Batley G, Maher WA. 2004. Monitoring of trace metals and metalloids in natural waters. In Environmental Monitoring Handbook, Burden FR, Donnert D, Godish T, Mckelvie I (eds). McGraw-Hill; 118 - 144.

Bermond A, Yousfi I, Ghestem JP. 1998. Kinetic approach to the chemical speciation of trace metals in soils. Analyst, 123: 785 - 789.

Calmano W, Mangold S, Welter E. 2001. An XAFS investigation of the artifacts caused by sequential extraction analyses of pb-contaminated soils. Fresenius J. Anal. Chem., 371: 823 - 830.

Campbell PGC. 1995. Interactions between trace metals and aquatic organisms: A critique of the free-ion activity model. In Metal Speciation and Bioavailability in 
Aquatic Systems, Tessier A, Turner DR (eds). Wiley: Chichester, UK; 45-102.

DEC. 1999. Sediment Criteria - Technical Guidiance for Screening Contaminated Sediment, Kenneth F, Wich GC (eds). New York State Department of Environmental Conservation, Division of Fish and Wildlife and Division of Marine Resources.

DPR (Department of Petroleum Resources). 2002. Environmental Guidelines and Standards for the Petroleum Industry in Nigeria (2nd edn). Department of Petroleum Resources, Ministry of Petroleum and Mineral Resources.

Egila JN, Nimyeh AND. 2002. Determination of trace metal speciation in sediment from some dams. J. Chem. Soc. Nig., 27(1): 71- 74 .

Förstner U. 1993. Metal speciation: General concepts and application. In Proceedings of a Workshop on Sequential Extraction of Trace Metals in Soils and Sediments, Rauret G. Quevauviller P (eds.). Int. J. Environ. Anal. Chem., 51: 5-23.

Gale NL, Adams CD, Wixson BG, Loftin KA, Huang Y. 2004. Lead, zinc, copper and cadmium in fish and sediments from the Rig River and Flat River Creek of Missouri's Old Lead Belt. Environ Geochem. and Health, 26: 37 - 49.

Gruebel KA, Davis JA, Lockie JO. 1988. The feasibility of using sequential extraction techniques for arsenic and selenium in soils and sediments. Soil Sci. Soc. Am. J., 52: 390 - 397.

Hendershot WH, Lalande H, Duquette $M$. 1993. Soil reaction and exchangeable Acidity. In Soil sampling and Methods of Analysis, Carter MR (ed). Canadian Society of Soil Science, Lewis Publishers: London; 141 - 145.

Lacatusu R. 2000. Appraising levels of soil contamination and pollution with heavy metals. European Soil Bureau, Research Report No 4.
Long ER, MacDonald DD, Smith SL, Calder ED. 1995. Incidence of adverse biological effects within ranges of chemical concentrations in marine and estuarine sediments. Environ. Managt., 19(1): 81 97.

Mudre JM, Ney JJ. 1986. Pattern of accumulation of heavy metal in the sediment of road sides streams. Arch. Environ. Toxicol., 15: 489-493.

Muohi AW, Onyari JM, Omondi JG, Mavuti KM. 2003. Heavy metals in sediments from Makupa and Port-Reitz Creek systems: Kenya Coast; Environ. Intern., 28: $639-647$.

Murphy CB. 1981. Bioaccumulation and toxicity of heavy metals and related trace elements. J. Water Pollut. Contrl. Fed., 53(6): 993 - 999.

Nolan AL, Lombi E, Malaughlin MJ. 2003. Metal bioaccumulation and toxicity in soils - why bother with speciation. Australian J. chem., 56(30): 77 - 91

Ostergren JD, Brown GE, Parts GA, Tingle TN. 1999. Quantitative speciation of lead in selected mine tailing from Leadville, Co. Environ. Sci. Technol., 33: 1627 1636.

Persaud D, Jaagumagi R, Hayton A. 1992. Guidelines for the Protection and Management of Aquatic Sediment Quality in Ontario, Ontario Ministry of Environment. Qeens's Printer for Ontario, p. 37.

Rauret G, Rubio R, Lopez - Sanchez JE, Casassas E. 1988. Analytical Chemistry. Specific Procedure for Metal Solid Speciation in Heavily Polluted River Sediments. Paper presented at the 3rd IAEAC workshop on Toxic metal compounds Follonical, Italy, April 1988: 89-100.

Rognerad S, Field E. 2001. Trace element contamination of Norwegian lake sediments. Ambio, 30(1): 11 - 19.

Sauz-metal A. 1998. Toxic trace metal speciation: importance and tools for 
environmental and biological analysis. Pure Appl. Chem., 70(12): 2281- 2285.

Scheinost ML, Kretzschmar R, Pfizer S. 2002. Combiring selective sequential extractions, X-ray absorption Spectroscopy, and principal component analysis for quantitative zinc speciation in soil. Environ. Sci. Technol., 36: 50215028.

Sheldrick BH, Wang C. 1993. Particle size distribution. In Soil Sampling and Methods of Analysis, Carter MR (ed). Canadian Society of Soil Science, Lewis Publishers: London; 449 - 511.

Tessier A, Campbell PGC. 1987. Partitioning of trace metals in sediments: Relationships with bioavailability. In Ecological Effects of in Situ Sediment Contaminants, Thomas R, Evans A, Hamilton A, Munawar M, Reynoldson T, Sadar H (eds). Hydrobiologia, 149: 4352.
US EPA (United State Environmental Protection Agency). 2008. Contaminated Sediment in Water. Retrieve from URL: http://www.epa.gov/waterscience/cs/abou tcs/index.html

US Geological Survey 1989. Methods for the determination of inorganic substances in water and fluvial sediments. Fishman MJ, Friedman LC (eds).. Techniques of Water Resources Investigation of the U.S Geological Survey Book 5 Chapter A1 US Government Printing Office, Washington DC.

Tack F, Verloo M. 1997. Characterization of metals in five flemish dredge materials sample. CATS congress, K. VIV, Antewerpen, Belgium.

Vitosh ML, Johnson .JW, Mengel B. 1995. Tri-state fertilizer recommendation for corn, soya bean and wheat in extension bulletin E.252, New York, p. 28. 